\title{
GAMBARAN PERSEPSI KELIRU TENTANG GIZI PADA IBU HAMILYANG MEMILIKI BALITA STUNTING DI DESA CIKUNIR KECAMATAN SINGAPARNA TAHUN 2019
}

\author{
Chanty Yunie Hartiningrum, SST., M.Kes \\ chanty.yunie@gmail.com \\ Rita Ayu N \\ Sekolah Tinggi Ilmu Kesehatan STIKes Respati Tasikmalaya
}

\section{A. ABSTRAK}

Budaya pada masa kehamilan dan persalinan di sebagian daerah telah terjadi pergeseran namun di sebagian lain masih dipertahankan. Hal ini seperti yang dijelaskan oleh O'Neil (2006) bahwa semua budaya yang diwariskan cenderung untuk berubah tetapi ada kalanya juga dipertahankan. Berdasarkan studi pendahuluan melalui wawancara singkat yang dilakukan di Di Wilayah Desa Cikunir Kabupaten Tasikmalayaterdapat ibu hamil yang memiliki kepercayaan-kepercayaan tentang acara makanan dan kebiasaan makan yang sudah turun-temurun dilakukan seperti contoh larangan untuk makan dipiring besar, makanan pedas, nanas, duren, tape dan yang lainya dengan alasan akan membahayakan kesehatan bayi. Metode penelitian ini menggunakan metode deskriptif.

Populasi dalam penelitian ini adalah seluruh ibu hamil sebanyak 41 orang pada tahun 2018. jumlah sampel sebanyak 41 orang. Pengumpulan data primer diperoleh langsung dari responden melalui kuesioner. Analisis data menggunakan analisis univariat dengan menggunakan rumus persentase.

Hasil penelitian menunjukkan bahwa umur ibu hamil mengubah persepsi keliru tentang mitos gizi pada masa kehamilan sebagai upaya pencegahan kejadian stunting sebanyak 18 orang (43,9\%), Yang Melakukan Budaya/Tradisi Syukuran Empat Bulanan dan Tujuh Bulanan sebanyak 32 yang melakukan (78,0\%), Memiliki Pantangan sebanyak 12 pantangan $(29,3 \%)$. Bagi ibu hamill hendaknya lebih memperhatikan kesehatan selama kehamilan, dengan cara mengkonsumsi makanan dengan menu seimbang (makan makanan bergizi) dan tidak ada pantangan pada ibu selama kehamilan dan sering memeriksakan kehamilan kepada petugas kesehatan/bidan.

Kata Kunci : Persepsi keliru, Kejadian Stunting 


\section{B. LATAR BELAKANG}

Di Era Digital 4.0 ini seharusnya masyarakat ber pola pikir ke arah yang lebih modern Dimana saat ini telah berkembang berbagai teknologi canggih yang dapat membantu masyarakat mengakses berbagai informasi yang akurat namun kenyataannya tak sedikit masyarakat percaya akan mitos khususnya masyarakat yang sedang berada dimasa kehamilan mereka masih cendrung percaya kepada mitos-mitos yang mengharuskan adanya pantangan makanan selama masa kehamilan yang selama ini berkembang pada masyarakakat yang lahir sejak dulu hal tersebut dikarenakan pengaruh budaya. Kebenarannya tidak dapat dipertanggung jawabkan namun. senantiasa beredar turun temurun. Memang tidak bisa dipungkiri mitos tentang berbagai hal selama masa kehamilan itu sudah menjadi warisan, tapi mitos yang ada itu tidak dapat dipastikan kebenarannya yang di kaji dalam segi medis.

Upaya untuk meningkatkan kualitas manusia harus dimulai sejak dini dari pertumbuhan janin yang tergantung pada status kesehatan ibu, Status gizi ibu sebelum dan selama hamil dapat mempengaruhi pertumbuhan janin yang sedang dikandung. Bila gtatus gizi ibu normal pada masa sebelum dan selama hamil kemungkinan besar akan melahirkan bayi yang sehat, cukup bulan 3 dengan berat badan normal. Dengan kata lain kualitas bayi yang dilahirkan sangat tergantung pada keadaan gizi ibu sebelum dan selama hamil Ibu hamil juga memerlukan makanan lebih banyak dari biasanya. Kehamilan merupakan suatu keadaan dimana seorang wanita yang didalam rahimnya terdapat embrio atau fetus. Kehamilan dimulai pada saat masa konsepsi hingga lahirnya janin, dan lamanya kehamilan dimulai dari ovulasi hingga partus yang diperkirakan sekitar 40 minggu dan tidak melebihi 43 minggu (Kuswanti, 2014). Jumlah ibu hamil di Indonesia pada tahun 2017 tercatat sekitar 5.324.562 jiwa. (Kemenkes RI, 2018). Kondisi kesehatan calon ibu pada masa awal kehamilan akan mempengaruhi tingkat keberhasilan kehamilan serta kondisi status kesehatan calon bayi yang masih didalam rahim maupun yang sudah lahir, sehingga disarankan agar calon ibu dapat menjaga perilaku hidup sehat dan menghindari faktorfaktor yang dapat mempengaruhi kondisi calon ibu pada masa kehamilan (Johnson, 2016). Sosial budaya dapat dilihat sebagai pola dalam suatu wilayah lokal, seringkali dipandang secara birokratis dan sesuatu yang terorganisir, berkembang, berbudaya termasuk teori pemikiran sistem kepercayaan dan aktivitas sehari-hari, hal ini dapat diterapkan dalam praktek keseharian. Terkadang sosial budaya digambarkan menjadi suatu yang tidak dapat ditangkap oleh akal sehat atau sesuatu diluar kemampuan panca indra (Cicourel, 2013). Kebudayaan memiliki unsur yang sama dalam setiap kebudayaan di dunia. Baik kebudayaan kecil bersahaja danterisolasi maupun yang besar, kompleks dan dengan jaringan hubungan yang luas. Kebudayaan sangat mudah berganti dan dipengaruhi oleh kebudayaan lain, sehingga akan menimbulkan berbagai masalah yang besar. Dalam suatu kebudayaan terdapat sifat sosialis masyarakat yang didalamnya terdapat suatu ikatan sosial tertentu yang akan menciptakan kehidupan bersama (Sulismadi \& Sofwani, 2011). Kebudayaan mencakup suatu pemahaman komprehensif yang sekaligus bisa diuraikan dan dilihat beragam vairabel dan cara memahaminya. Kebudayaan dalam arti suatu pandangan yang menyeluruh yang menyangkut pandangan hidup, sikap dan nilai. Pembangunan kebudayaan dikaitkan dengan upaya memperbaiki kemampuan untuk recovery, bangkitdari kondisi yang buruk, bangkit untuk memperbaiki kehidupan bersama, bangkit untuk menjalin kesejahteraan. Dalam hal inilah sosial budaya 
berperan untuk 3 memberikan solusi terbaik bagi beragam bidang kehidupan (Widianto \& Pirous, 2009). Budaya pada masa kehamilan dan persalinan di sebagian daerah telah terjadi pergeseran namun di sebagian lain masih dipertahankan. Hal ini seperti yang dijelaskan oleh O'Neil (2006) bahwa semua budaya yang diwariskan cenderung untuk berubah tetapi ada kalanya juga dipertahankan. Ada proses dinamis yang mendukung diterimanya hal-hal dan ide-ide baru dan ada juga yang mendukung untuk mempertahankan kestabilan budaya yang ada. Hiller (2003) menyatakan bahwa ketika perubahan terjadi, maka terjadi destruksi nilainilai tradisional, kepercayaan, peran dan tanggungjawab, pendidikan, keluarga dan lain-lain yang hampir simultan dengan proses konstruksi cara baru sebagai pengaruh dari perubahan sosial. Nilai dan ritual yang baru ini menggantikan nilai dan ritual yang lama. Namun di sebagian masyarakat adakalanya terjadi kompromi yang mana nilai dan ritual baru dijalankan dengan tanpa menghilangkan nilai dan ritual lama.

Berdasarkan studi pendahuluan melalui wawancara singkat yang dilakukan di Di Wilayah Desa Cikunir Kabupaten Tasikmalayaterdapat ibu hamil yang memiliki kepercayaankepercayaan tentang acara makanan dan kebiasaan makan yang sudah turun temurun dilakukan seperti contoh larangan untuk makan dipiring besar, makanan pedas, nanas, duren, tape dan yang lainya dengan alasan akan membahayakan kesehatan bayi. Berdasarkan latar belakang tersebut peneliti tertarik untuk meneliti Persepsi Keliru Tentang Gizi pada Ibu Hamil yang Memiliki Balita Stunting di Desa Cikunir Kecamatan Singaparna Tahun 2019.

\section{METODE PENELITIAN}

Penelitian ini adalah penelitian observasional kuantitatif dengan rancangan penelitian deskriptif. Penelitian ini menggambarkan Gambaran Persepsi Persepsi
Keliru Tentang Gizi pada Ibu Hamil yang Memiliki Balita Stunting di Desa Cikunir Kecamatan Singaparna Tahun 2019.

\section{A. Subjek Penelitian}

1. Populasi Penelitian

Populasi dalam penelitian ini adalah semua ibu hamil di Desa Cikunir Kecamatan Singaparna Tahun 2019.

2. Sampel Penelitian

Sampel penelitian ini adalah ibu hamil di RW 05 dengan teknik pengambilan sampling secara simple random sampling berjumlah 41 ibu hamil.

\section{B. Waktu dan Tempat Penelitian}

Waktu penelitian dilakukan pada tanggal 15-20 Novemver 2019. Tempat penelitian di Desa Cikunir. 


\section{HASIL PENELITIAN}

\section{A. HASIL PENELITIAN}

\section{Analisis Univariat Karakteristik Responden}

Berdasarkan hasil penelitian dapat diketahui gambaran karakteristik responden penelitian di Desa Cikunir sebagai berikut:

a. Kriteria Responden

Tabel 4.1

Karakteristik ibu hamil berdasarkan umur di Wilayah Desa Cikunir Kabupaten Tasikmalaya Tahun 2018

\begin{tabular}{lcc}
\hline \multicolumn{1}{c}{ Umur } & Jumlah & \% \\
\hline Resiko $(<20$ Tahun, $>35$ Tahun $)$ & 10 & 24.4 \\
\hline Tidak Beresiko (20-35 Tahun) & 31 & 75.6 \\
\hline Total & $\mathbf{4 1}$ & $\mathbf{1 0 0 . 0}$ \\
\hline
\end{tabular}

Berdasarkan tabel 4.1 Karaketristik ibu hamil berdasarkan umur di Wilayah Desa Cikunir Kabupaten Tasikmalaya Tahun 2018 sebagian besar termasuk kelompok umur tidakberesiko atau berkisar antara 20-35 tahun yaitu sebanyak 31 orang (75.6\%).

Tabel 4.2

Karakteristik ibu hamil berdasarkan pekerjaan di Wilayah Desa Cikunir Kabupaten Tasikmalaya Tahun 2018

\begin{tabular}{lcc}
\hline \multicolumn{1}{c}{ Pekerjaan } & Jumlah & Persentase \\
\hline Ibu Rumah Tangga & 33 & 80.5 \\
\hline Buruh & 7 & 17.1 \\
\hline Pegawai swasta & 1 & 2.4 \\
\hline Total & 41 & 100.0 \\
\hline
\end{tabular}

Berdasarkan tabel 4.2 Pekerjaan yang dilakukan ibu hamil di Wilayah Desa Cikunir Kabupaten Tasikmalaya Tahun 2018 adalah sebagai ibu rumah tangga yaitu sebanyak 33 orang $(80.5 \%)$.

Tabel 4.3

Karakteristik ibu hamil berdasarkan Pendidikan di Wilayah Desa Cikunir Kabupaten Tasikmalaya Tahun 2018

\begin{tabular}{lcc}
\hline \multicolumn{1}{c}{ Pendidikan } & Jumlah & Persentase \\
\hline Tidak Tamat SD & 7 & 17.1 \\
\hline Pendidikan Dasar (SD) & 28 & 68.3 \\
\hline Pendidikan Menengah (SMP, SMA) & 5 & 12.2 \\
\hline Perguruan Tinggi (PT) & 1 & 2.4 \\
\hline
\end{tabular}


Berdasarkan tabel 4.3 Karakteristik ibu hamil berdasarkan pendidikan di Wilayah Desa Cikunir Kabupaten Tasikmalaya Tahun 2018 sebagian besar termasuk berpendidikan dasar (lulusan dari SD) yaitu sebanyak 28 orang (68.3\%).

Tabel4.4

Karakteristik ibu hamil berdasarkan paritas di Wilayah Desa Cikunir Kabupaten Tasikmalaya Tahun 2018

\begin{tabular}{lccc}
\hline & Paritas & Jumlah & Persentase \\
\hline Primigravida & 11 & 26.8 \\
\hline Multigravida & 23 & 56.1 \\
\hline Grandegravida & 7 & 17.1 \\
\hline Total & 41 & 100.0 \\
\hline
\end{tabular}

Berdasarkan tabel 4.4 Karakteristik ibu hamil berdasarkan paritas di Wilayah Desa Cikunir Kabupaten Tasikmalaya Tahun 2018 sebagian besar termasuk multigravida yaitu sebanyak 23 orang (56.1\%).

Tabel 4.5

Karakteristik ibu hamil berdasarkan usia kehamilan di Wilayah Desa Cikunir Kabupaten Tasikmalaya Tahun 2018

\begin{tabular}{|c|c|c|}
\hline Usia kehamilan & Jumlah & Persentase \\
\hline Trimester 1 & 9 & 22.0 \\
\hline Trimester 2 & 14 & 34.1 \\
\hline Trimester 3 & 18 & 43.9 \\
\hline Total & 41 & 100.0 \\
\hline
\end{tabular}

Berdasarkan tabel 4.5 Karakteristik ibu hamil berdasarkan usiakehamilan di Wilayah Desa Cikunir Kabupaten Tasikmalaya Tahun 2018 sebagian besar adalah trimester III yaitu sebanyak 18 orang (43.9\%).

Tabel4.6

Distribusi ibu hamil yang Melakukan Budaya/Tradisi Syukuran Empat Bulanan dan Tujuh Bulanan di Wilayah Desa Cikunir Kabupaten Tasikmalaya Tahun 2018

\begin{tabular}{lcc}
\hline $\begin{array}{c}\text { Pelaksanaan Budaya/tradisi Syukuran } \\
\text { Empat Bulanan dan Tujuh Bulanan }\end{array}$ & Jumlah & Persentase \\
\hline Ya & 32 & 78.0 \\
\hline Tidak & 9 & 22.0 \\
\hline Total & 41 & 100.0 \\
\hline
\end{tabular}


Berdasarkan tabel 4.6 Ibu hamil di Wilayah Desa Cikunir Kabupaten Tasikmalaya Tahun 2018 yang melakukan kebiasaan atau tradisi dilingkungan terkait dengan kehamilan sebanyak 32 orang $(78.0 \%)$.

Tabel 4.7

Distribusi ibu hamil yang Memiliki Pantangan di Wilayah Desa Cikunir Kabupaten Tasikmalaya Tahun 2018

\begin{tabular}{lcc}
\hline \multicolumn{1}{c}{ Pantangan ibu hamil } & Jumlah & Persentase \\
\hline Tidak ada pantangan & 6 & 14.6 \\
\hline $\begin{array}{l}\text { Tidak boleh makan pisang dari pohon } \\
\text { yang sudah tumbang }\end{array}$ & 1 & 2.4 \\
\hline Menjawab 2 Pertanyaan & 1 & 2.4 \\
\hline Menjawab 3 Pertanyaan & 8 & 19.5 \\
\hline Menjawab 4 Pertanyaan & 2 & 4.9 \\
\hline Menjawab 5 Pertanyaan & 9 & 22.0 \\
\hline Menjawab 6 Pertanyaan & 12 & 29.3 \\
\hline Menjawab 7 Pertanyaan & 1 & 2.4 \\
\hline Menjawab 8 Pertanyaan & 1 & 2.4 \\
\hline Total & 41 & 100.0 \\
\hline
\end{tabular}

Berdasarkan tabel 4.7 Ibu hamil di Wilayah Desa Cikunir Kabupaten Tasikmalaya Tahun 2018 yang memiliki pantangan makanan selama kehamilan sebagian besar memiliki 6 pantangan makanan yang tidak boleh dikonsumsi yaitu sebanyak 13 orang (31.7\%).

Tabel 4.8

Distribusi Jenis Pantangan/Larangan Yang Harus Diikuti Ibu Pada Saat Hamildi Wilayah Desa Cikunir Kabupaten Tasikmalaya Tahun 2018

\begin{tabular}{lcc}
\hline \multicolumn{1}{c}{ Tidak Ada Pantangan } & Jumlah & Persentase \\
\hline Setuju & 6 & 14.6 \\
\hline Tidak Setuju & 35 & 85.4 \\
\hline Total & 41 & 100.0 \\
\hline
\end{tabular}

Berdasarkan tabel 4.8 didapatkan bahwa ibu hamil yang tidak setuju tidak ada pantangan sebanyak 35 orang $(85.4 \%)$. 
Tabel 4.9

Distribusi Jenis Pantangan/Larangan Yang Harus Diikuti Ibu Pada Saat Hamil di Wilayah Desa Cikunir Kabupaten Tasikmalaya Tahun 2018

\begin{tabular}{lcc}
\hline \multicolumn{1}{c}{ Jangan Makan dipiring besar } & Jumlah & Persentase \\
\hline Setuju & 27 & 65.9 \\
\hline Tidak Setuju & 14 & 34.1 \\
\hline Total & 41 & 100.0 \\
\hline
\end{tabular}

Berdasarkan tabel 4.9 didapatkan bahwa ibu hamil tidak boleh makan dipiring besar yang setuju sebanyak 27 orang $(65.9 \%)$.

Tabel 4.10

Distribusi Jenis Pantangan/Larangan Yang Harus Diikuti Ibu Pada Saat Hamildi Wilayah Desa Cikunir Kabupaten Tasikmalaya Tahun 2018

\begin{tabular}{lcc}
\hline \multicolumn{1}{c}{$\begin{array}{c}\text { Jangan Makan pisang dari pohon } \\
\text { tumbang }\end{array}$} & Jumlah & Persentase \\
\hline Setuju & 24 & 58.5 \\
\hline Tidak Setuju & 17 & 41.5 \\
\hline Total & 41 & 100.0 \\
\hline
\end{tabular}

Berdasarkan tabel 4.9 didapatkan bahwa ibu hamil tidak boleh Makan pisang dari pohon tumbang yang setuju sebanyak 24 orang $(58.5 \%)$.

Tabel 4.10

Distribusi Jenis Pantangan/Larangan Yang Harus Diikuti Ibu Pada Saat Hamildi Wilayah Desa Cikunir Kabupaten Tasikmalaya Tahun 2018

\begin{tabular}{lcc}
\hline \multicolumn{1}{c}{ Jangan Minum Air ES } & Jumlah & Persentase \\
\hline Setuju & 25 & 61.0 \\
\hline Tidak Setuju & 16 & 39.0 \\
\hline Total & 41 & 100.0 \\
\hline
\end{tabular}

Berdasarkan tabel 5.10 didapatkan bahwa ibu hamil tidak boleh minum air ESyang setuju sebanyak 25 orang $(61.0 \%)$. 
Tabel 4.11

Distribusi Jenis Pantangan/Larangan Yang Harus Diikuti Ibu Pada Saat Hamildi Wilayah Desa Cikunir Kabupaten Tasikmalaya Tahun 2018

\begin{tabular}{lcc}
\hline $\begin{array}{c}\text { Makan Pedas Menyebabkan Bayi Lahir } \\
\text { Sakit }\end{array}$ & Jumlah & Persentase \\
\hline Setuju & 25 & 61.0 \\
\hline Tidak Setuju & 16 & 39.0 \\
\hline Total & 41 & 100.0 \\
\hline
\end{tabular}

Berdasarkan tabel 4.11 didapatkan bahwa ibu hamil tidak boleh Makan Pedas Menyebabkan Bayi Lahir Sakit setuju sebanyak 25 orang (61.0\%).

Tabel 4.12

Distribusi Jenis Pantangan/Larangan Yang Harus Diikuti Ibu Pada Saat Hamildi Wilayah Desa Cikunir Kabupaten Tasikmalaya Tahun 2018

\begin{tabular}{lcc}
\hline \multicolumn{1}{c}{ Tidak Boleh Makan Nanas, Duren, } & Jumlah & Persentase \\
Tape & 21 & 51.2 \\
\hline Setuju & 20 & 48.8 \\
\hline Tidak Setuju & 41 & 100.0 \\
\hline Total & \\
\hline
\end{tabular}

Berdasarkan tabel 4.12 didapatkan bahwa ibu hamil tidak boleh Tidak boleh makan nanas, duren, tape setuju sebanyak 21 orang $(51.2 \%)$.

Tabel 4.13

Distribusi Jenis Pantangan/Larangan Yang Harus Diikuti Ibu Pada Saat Hamildi

Wilayah Desa Cikunir Kabupaten Tasikmalaya Tahun 2018

\begin{tabular}{lcc}
\hline \multicolumn{1}{c}{ Sering Minum Air Kelapa Muda } & Jumlah & Persentase \\
\hline Setuju & 25 & 61.0 \\
\hline Tidak Setuju & 16 & 39.0 \\
\hline Total & 41 & 100.0 \\
\hline
\end{tabular}

Berdasarkan tabel 4.13 didapatkan bahwa ibu hamil Sering Minum Air Kelapa Muda setuju sebanyak 25 orang $(61.0 \%)$. 
Tabel 4.14

Distribusi Jenis Pantangan/Larangan Yang Harus Diikuti Ibu Pada Saat Hamildi Wilayah Desa Cikunir Kabupaten Tasikmalaya Tahun 2018

\begin{tabular}{lcc}
\hline \multicolumn{1}{c}{ Sering Minum Minyak Kelapa } & Jumlah & Persentase \\
\hline Setuju & 27 & 65.9 \\
\hline Tidak Setuju & 14 & 34.1 \\
\hline Total & 41 & 100.0 \\
\hline
\end{tabular}

Berdasarkan tabel 5.14 didapatkan bahwa ibu hamil Sering Minum Minyak Kelapa Muda setuju sebanyak 27 orang (65.9\%).

Tabel 4.14 Distribusi Jenis Pantangan/Larangan Yang Harus Diikuti Ibu Pada Saat Hamildi Wilayah Desa Cikunir Kabupaten Tasikmalaya Tahun 2018

\begin{tabular}{lcc}
\hline \multicolumn{1}{c}{$\begin{array}{c}\text { Minum Madu dan Kocokan Telur } \\
\text { Ayam }\end{array}$} & Jumlah & Persentase \\
\hline Setuju & 27 & 65.9 \\
\hline Tidak Setuju & 14 & 34.1 \\
\hline Total & 41 & 100.0 \\
\hline
\end{tabular}

Berdasarkan tabel 4.15 didapatkan bahwa ibu hamilMinum Kocokan telur ayamsetuju sebanyak 27 orang (65.9\%)

\section{E. PEMBAHASAN \\ Pantangan/Larangan Yang Harus Diikuti Ibu Pada Saat Hamil}

\section{Jangan Makan dipiring besar} Berdasarkan hasil penelitian didapatkan bahwa responden memiliki persepsi bahwa ibu hamil tidak boleh makan dipiring besar yaitu 27 orang (65.9\%). Hal ini tidak sesuai dengan teori dimana kebutuhan gizi ibu hamil merupakan hal yang penting yang harus yang harus dipenuhi selama kehamilan berlangsung. Resiko akan kesehatan janin yang sedang dikandung dan ibu yang mengandung akan berkurang jika ibu hamil mendapatkan gizi dan nutrisi yang seimbang. Oleh karna itu keluarga dan ibu hamil haruslah memperhatikan mengenai hal ini. Gizi atau nutrisi ibu hamil kondisinya sama saja dengan pengaturan gizi mengenai pola makan yang sehat.Kebutuhan gizi ibu hamil meninkat $15 \%$ dibandingkan dengan kebutuhan wanita normal. Peningkatan gizi ini di butuhkan untuk pertumbuhan ibu dan janin. Makanan dikonsumsi ibu hamil 40\% digunakan untuk pertumbuhan janin dan sisanya 60\% digunakan untuk pertumbuhan ibunya. Secara normal kenaikan Berat Badn Ibu Hamil berkisar antara $12-14 \mathrm{~kg}$.

\section{Jangan Makan Pisang dari Pohon yang Tumbang}

Berdasarkan hasil penelitian didapatkan bahwa responden memiliki persepsi bahwa Jangan Makan Pisang dari Pohon yang Tumbang yaitu 24 orang (58.5\%). Karna memakan pisang dari pohon yang tumbang dapat mengakibatkan rahimnya keluar ini merupakan keyakinan/tradisi ibu akibat budaya yang diyakininya.Menurut 
Susiloningtyas (2007), Kebutuhan nutrisi salah satunya adalah zat besi selama hamil dengan rata-rata $800 \mathrm{mg}-$ 1040mg. Kebutuhan ini diperlukan untuk : $\pm 300 \mathrm{mg}$ diperlukan untuk pertumbuhan janin, $\pm 50 \mathrm{mg}-75 \mathrm{mg}$ untuk pembentukan plasenta, $\pm 500 \mathrm{mg}$ digunakan untuk meningkatkan massa hemoglobin maternal atau sel darah merah, $\pm 200 \mathrm{mg}$ lebih akan dieksresikan lewat usus, urin, dan kulit, serta $\pm 200 \mathrm{mg}$ lenyap ketika melahirkan.

Pisang sejak lama telah dikenal sebagai buah lezat dan berkhasiat bagi kesehatan. Buah pisang mengandung kalium (potasium) yang bermanfaat untuk penyeimbangan $\mathrm{pH}$ atau derajat keasaman didalam lambung (Lalage, 2013). Selain itu, kalium. bermanfaat untuk pengendalian tekanan darah, memengaruhi irama jantung, terapi darah tinggi, membersihkan karbondioksida didalam darah, berperan dalam kepekatan saraf dan otot, serta memicu kerja otot dan simpul saraf (Astrawan, 2008). Kalium yang tinggi juga akan memperlancar pengiriman oksigen ke otak dan membantu keseimbangan cairan di dalam tubuh (Kowalski, 2010).

\section{Jangan Minum Air ES}

Berdasarkan hasil penelitian didapatkan bahwa responden memiliki persepsi bahwa ibu hamil yang mengkonsumsi Air es beresiko bahwa bayi yang dikandungnya anak lahir tidak normal (bayi besar) sebanyak 25 responden $(61.0 \%)$.

Hal ini tidak sesuai dengan teori yang menyebutkan bahwa ibu yang mengkonsumsi air es atau minuman dingin selama masa kehamilan seperti es krim, sirup dan minuman yang lainya mengandung es akan melahirkan bayi dengan ukuran yang lebih besar dibandingkan pada berat yang normal.
Padahal air es dan bayi tidak ada hubunganya sama sekali. Bayi besar atau yang disebut dengan makrosomia ini adalah dimana kondisi bayi yang lahir dengan berat badan lebih dari 4 kg. Hal ini umumnya di sebabkan oleh ibu hamil yang mengidap penyakit diabetes (kencing manis).

Ibu yang mengkonsumsi air es selama kehamilan tidak berpengaruh dengan bayi besar, yang dapat menyebabkan bayi besar apabila ibu hamil mengkonsumsi air es ditambah dengan pemanis (gula, sirup dan yang lainya).

Pemanis merupakan senyawa kimia yang sering digunakan untuk keperluan produk olahan pangan, industri serta minuman dan makanan kesehatan. Menurut Peraturan Menteri Kesehatan (Menkes) RI Nomor 235, pemanis termasuk ke dalam bahan tambahan kimia, selain zat yang lain seperti antioksidan, pemutih, pengawet, dan lain sebagainya. Pemanis berfungsi untuk meningkatkan cita rasa dan aroma, memperbaiki sifat-sifat fisik, sebagai pengawet, dan untuk memperbaiki sifatsifat kimia sekaligus merupakan sumber kalori bagi tubuh.

\section{Makanan Pedas menyebabkan Bayi Lahir Sakit}

Berdasarkan hasil penelitian didapatkan bahwa responden memiliki persepsi bahwa ibu hamil yang mengkonsumsi Makanan Pedas menyebabkan Bayi Lahir Sakit sebanyak 25 responden (61.0\%).

Hal ini tidak sesuai dengan teori yang menyatakan bahwa makanan pedas tidak baik dikonsumsi oleh ibu hamil. Berikut dampak makanan pedas bagi ibu hamil :

a. Heartburn

Salah satu bahaya yang bisa ditimbulkan jika ibu hamil sering makan- 
makanan yang pedas akan mengalami heartburn adalah kondisi dimana dada terasa sesak dan nafas setelah makan. Makan-makanan yang pedas selama masa kehamilan bisa menyebabkan anda mengalami heartburn dan juga bisa meningkatkan asam lambung.

b. Moorning Sickness

Bahaya jika ibu terlalu sering makan-makanan pedas selama masa kehamilan yang kedua adalah bisa memperburuk morning sickness yang ibu alami. Morning sickness ini diiringi gejala seperti mual, muntah, pusing, perut tak nyaman dan bisa jadi tambah parah jika ibu makanmakanan pedas. Ibu hamil juga harus tahu bagaimana cara mengatasi Morning sickness.

\section{c. Maag}

Bagi ibu yang suka makan pedas dalam keadaan ibu sedang hamil lebih besar beresiko terkena maag atau asam lambung.

d. Perut terasa tidak nyaman

Perut terasa tidak nyaman atau perut terasa mulas karna makanan yang di konsumsi ibu hamil makanan pedas bisa membuat ibu terkena sakit perut yang disertai dengan gejala infeksi. Jika sudah sangat parah maka akan menyebabkan diare yang berlebihan.

e. Kontraksi

Makanan pedas bisa membantu meningkatkan pelepasan hormon prostaglandin yang mana bisa menyebabkan otot menginduksi sehingga bisa menyebabkan kontraksi. Kontraksi ini akan kita rasakan seperti mau melahirkan.

Hal ini sesuai dengan hasil penelitian Sinta Fitriani, S.KM, M.KM dalam Jurnal Kesehatan Bidkesmas Respati, Volume 1, Nmor 10 Februari 2019 "Berdasarkan hasil penelitian didapatkan bahwa responden memiliki persepsi bahwa ibu hamil yang mengkonsumsi makanan pedas mendapatkan anak dengan muka dengan kemerahan yaitu 105 orang (64\%).

\section{Tidak Boleh Makan Nanas, Duren dan Tape}

Berdasarkan hasil penelitian didapatkan bahwa responden memiliki persepsi bahwa ibu hamil tidak boleh makan Nanas, Duren dan tape sebanyak 21 responden (51.2\%).

Masyarakat di Desa Cikunir mempunyai pantangan tidak meboleh makan Nanas, Duren dan Tape karna makanan tersebut membuat ibu hamil terjadi keguguran, pantangan ini sudah dari turun temurun nenek moyangnya.

Buah yang hampir ditabukan oleh berbagai suku/daerah di Indonesia adalah buah nenas. Masyarakat percaya bahwa ibu hamil yang mengonsumsi buah nanas akan menyebabkan keguguran, "Landep", menyebabkan korengan, diare, proses persalinan akan sulit dan kulit bayi bersisik, gatal, kepala anak seperti nanas, menyebabkan panas pada janin, anak akan membesar sehingga sulit saat persalinan, dan membahayakan janin. Buah nanas mengandung enzim bromelin yang dapat menstimulasi pengeluaran prostaglandin. Kadar prostaglandin yang meningkat dapat menyebabkan stimulasi kontraksi uterus. Selain itu, buah nanas juga mengandung serotonin yang juga memiliki peran dalam merangsang kontraksi uterus.

Durenmengandung senyawa sulfur yang disebut dietil disulfida yang dapat menghambat kerja enzim aldehyde dehydrogenase (ALDH) dalam hati yang berfungsi untuk memecah alkohol. Ditambah lagi, durian sudah tinggi kalori, jadi menambahkan alkohol akan membuat hal sulit bagi perut dan hati untuk mencerna makanan. Hal ini dapat menyebabkan gejala hangover yang berlebihan. Kadar alkohol dalam darah 
yang gagal dipecah oleh tubuh, karena dihambat oleh durian akan berubah menjadi sangat beracun. Anda dapat menjadi sangat kebingungan, tidak responsif, mengalami pernapasan pendek, bahkan kehilangan kesadaran hingga koma. Selain itu, meski durian tidak mengandung kolesterol dan lemak jenuh, makan durian tetap bisa meningkatkan tekanan darah.Kadar alkohol yang terlalu tinggi dalam tubuh bisa makin menyebabkan tekanan darah Anda melonjak di luar batas. Hipertensi kemudian

$\begin{array}{llr}\text { meningkatkan } & \text { risiko } & \text { Anda } \\ \text { mengalami serangan jantung, } & \text { jant } \\ \text { stroke, atau gagal jantung } \\ \text { kongestif. }\end{array}$

Tingkat alkohol dalam darah yang melebihi batas wajar juga dapat melemahkan otot-otot jantung, yang juga akan mempengaruhi paru, hati, otak, dan sistem organ dalam tubuh lainnya. Kadar alkohol yang terlalu tinggi dalam darah dapat menyebabkan kerusakan otak permanen dan menyebabkan jantung berdetak tidak normal (aritmia jantung), yang telah dikaitkan dengan kematian mendadak.

Kandungan dalam tape terdapat kadar alkohol yang dikandungnya, dapat menyebabkan terjadinya faktor resiko mengalami penyakit hati. Hal ini dikarenakan alkohol dimetabolisme di dalam organ hati, sehingga membuat organ hati bekerja lebih berat. Penyakit hati paling sering terjadi akibat kebiasaan mengkonsumsi alkohol adalah sirosis hati. Walaupun ada yang mengatakan bahwa kandungan alkohol dari tape tidak begitu besar, namun tetap saja hal tersebut akan menjadi akumulasi pada saat sering dikonsumsi. Selain itu dalam beberapa pendapat mengatakan, bahwa ketika mengkonsumsi tape singkong selain dapat menyebabkan resiko penyakit hati pada Ibu hamil, diduga juga dapat merusak atau memicu gangguan hati juga pada janin. Hal ini dikarenakan setelah Ibu mengkonsumsi tape, maka alkohol di kangdungannya akan terbawa di dalam darah dan kemudian menembus plasenta lalu masuk ke tubuh janin. Dari situ di dalam tubuh janin, organ hatinya juga akan ikut dalam proses metabolisme alkohol sehingga ketika bayi lahir, bisa saja bayi mengalami gangguan fngsi hati dan tampak kuning.

Beberapa penelitian telah membuktikan bahwa terdapat hubungan yang signifikan antara konsumsi nanas muda dengan kontraksi uterus. Namun prinsipnya, kandungan bromelin akan menurun seiring dengan bertambahnya tingkat kematangan nanas. Hasil penelitian Apsari et al.(2012) menunjukkan terdapat hubungan yang signifikan antara pemberian ekstrak buah nanas baik yang muda ataupun tua terhadap kontraksi uterus marmut. Namun, pemberian ekstrak buah nanas muda lebih kuat pengaruhnya terhadap peningkatan kontraksi uterus

dibandingkan ekstrak buah nanas tua. Mungkin, hal inilah yang dapat menjelaskan secara ilmiah mengapa konsumsi buah nanas ditabukan bagi ibu hamil. Tetapi, menurut hasil penelitian Sari, kebiasaan mengonsumsi buah nanas oleh ibu di atas usia kehamilan di atas 36 minggu dapat dilakukan dengan catatan ibu hamil normal tanpa komplikasi dan ibu hamil yang usia kehamilannya sudah matur (Sari, 2010)

\section{Sering Minum Air Kelapa Muda}

Berdasarkan hasil penelitian didapatkan bahwa responden memiliki persepsi bahwa ibu hamil yang sering minum air kelapa muda yang setuju sebanyak 25 responden $(61.0 \%)$ dan tidak setuju 16 responden $(39.0 \%)$.

Pada masyarakat ini beramsumsi 
bahwa ibu hamil yang sering minum air kelapa muda sangat bagus untuk kehamilan terutama pada kehamilan usia

4 bulan ke atas, meraka beramsusi bahwa kandungan dalam air kelapa muda bagus untu janin dan untuk memperbanyak air ketuban pada kehamilan ibu.

Selama menjalani masa kehamilan, ibu hamil bisa mengonsumsi air kelapa karena memiliki sejumlah manfaat bagi ibu dan janin. Manfaat tersebut antara lain :

\section{a. Sumber elektrolit dan antioksidan}

Air kelapa mengandung elektrolit, minum air kelapa bisa mengganti asupan elektrolit yang terbuang saat muntah pada ibu hamil yang mengalami morning sickness. Air kelapa pun mengandung antioksidan yang membantu melenyapkan radikal bebas di tubuh. Untuk hasil yang maksimal, pilihlah air kelapa segar, bukan air kelapa kemasan.

\section{b. Membantu mengurangi kelelahan}

Kandungan elektrolit dalam air kelapa sangat baik dalam mengganti cairan tubuh yang hilang sehingga ibu hamil terhindar dari dehidrasi. Garam alami pada tubuh dapat digantikan dengan air kelapa karena mengandung garam alami seperti natrium, kalium, dan klorida.

\section{c. Mencegah infeksi saluran kencing} Keluhan yang cukup sering dialami ibu hamil adalah infeksi saluran kencing karena adanya perubahan hormon dan perkembangan rahim yang menekan kandung kemih. Air kelapa adalah diuretik alami yang akan membuat ibu hamil lebih mudah untuk mengeluarkan urine dan mencegah terjadinya infeksi saluran kemih. Beberapa wanita terbantu dalam mencegah infeksi saluran kemih dengan mengonsumsi air kelapa.

\section{d. Melancarkan sirkulasi darah}

Air kelapa untuk ibu hamil juga berguna untuk mengurangi pegal dan nyeri yang diakibatkan tidak optimalnya sistem sirkulasi darah. Jika sistem sirkulasi darah tidak optimal, maka janin berisiko tidak mendapatkan suplai oksigen yang cukup. Kalium dan magnesium yang terdapat dalam air kelapa berperan penting dalam memompa darah ke seluruh tubuh dari jantung. Kalium juga membantu gerakan otot, penghantaran sinyal saraf, dan membantu kerja ginjal dalam penyaringan darah.

Menurut Kemala dan Velayutham (1978), nilai gizi pada air buah kelapa muda, terutama mineral komposisi tertinggi adalah pada umur buah 8 bulan dan mineral $\mathrm{K}$ adalah yang paling tinggi. Oleh karena itu berbagai penelitian menunjukkan bahwa penggunaan air kelapa dapat menyembuhkan beberapa penyakit. Jika ditelusuri susunan komposisi gizi dari jenis-jenis susu formula, maka hampir semua komposisi makro maupun mikronutrien pada daging dan air kelapa muda, terkandung pada susu formula.

\section{Sering Minum Minyak Kelapa}

Berdasarkan hasil penelitian didapatkan bahwa responden memiliki persepsi bahwa ibu hamil yang sering minum minyak kelapa yang setuju sebanyak 27 responden $(65.9 \%)$ dan tidak setuju 14 responden $(34.1 \%)$.

$$
\text { Pada masyarakat ini }
$$

beramsumsi bahwa ibu hamil yang sering minum minyak kelapa sangat bagus untuk melancarkan kelahiranya karna minum minyak kelapa akan membuat persalinan menjadi lancar karna banyak mengandung minyak.

Buah kelapa memilki cukup banyak manfaat, yaitu sebagai minyak makan atau santan dalam sayur-sayuran. Minyak kelapa murni

mengandung asam laurat yang tinggi. Asam laurat adalah asam lemak jenuh yang berantai 
medium atau biasa disebut Medium Chain Fatty Acid (MCFA). Dalam minyak kelapa murni terkandung energi sebanyak 6,8 kal/gr dan MCFA sebanyak 92\% (Gani, 2005).

Saat ini minyak kelapa banyak digunakan sebagai obat. Minyak kelapa yang dijadikan sebagai obat biasanya disebut minyak kelapa murni (virgin coconut oil/ VCO). Berbagai penyakit yang berasal dari virus dapat ditangkal dengan mengkonsumsi minyak kelapa murni, seperti flu burung, HIV/AIDS, hepatitis, dan jenis virus lainnya. Selain itu, minyak kelapa murni dapat juga mengatasi kegemukan, penyakit kulit, darah tinggi, dan diabetes (Sutarmi dan Rozaline, 2005).

Menurut SNI 7381:2008 minyak kelapa murni adalah minyak yang diperoleh dari daging buah kelapa (Cocos nucifera L.) tua yang segar dan

diproses dengan diperas dengan atau tanpa penambahan air, tanpa pemanasan atau pemanasan tidak lebih dari $600 \mathrm{C}$ dan aman untuk dikonsumsi. Minyak kelapa murni tidak berwarna (bening), tidak berasa, serta mempunyai aroma yang harum dan khas (Gani, 2005).

Minyak kelapa murni mempunyai sifat tahan terhadap panas, cahaya, oksigen, dan proses degradasi. Sifat itu membuat minyak kelapa murni dapat disimpan dalam jangka waktu yang lama. Dalam pemanfaatannya, minyak kelapa murni dapat dikonsumsi secara langsung ataupun dicampur dengan makanan (Gani, 2005).

VCO mempunyai

kandungan asam lemak jenuh yang tinggi. VCO mengandung sekitar 92\% asam lemak jenuh yang terdiri dari asam laurat, miristat, dan palmitat. Kandungan asam lemak jenuh dalam VCO didominasi oleh asam laurat dan asam miristat, sedangkan kandungan asam lemak lainnya rendah. Tingginya asam lemak jenuh yang dikandungnya menyebabkan VCO tahan terhadap proses ketengikan akibat oksidasi (Syah, 2005).

9. Minum Madu dan Kocokan Telur Ayam

Berdasarkan hasil penelitian didapatkan bahwa responden memiliki persepsi bahwa ibu hamil yang Minum Madu dan Kocokan Telur Ayam yang setuju sebanyak 27 responden (65.9\%) dan tidak setuju 14 responden $(34.1 \%)$.

Pada masyarakat ini beramsumsi bahwa ibu hamil yang sering minum madu dan kocokan telur ayam sangat bagus untuk kehamilan terutama pada pada bayi yang didalam kandungan ibu dan ibu hamilpun akan merasa sehat dan stamina yang kuat selama kehamilan dan persiapan untuk persalinanya.

Madu merupakan salah satu sumber makanan yang baik. Madu bermanfaat sebagai makanan kesehatan yang dapat meningkatkan stamina tubuh sebagai energi seketika. Selain itu madu juga dapat digunakan sebagai pengganti gula atau suplementasi nutrisi. Produk lebah ini dapat menyembuhkan berbagai macam penyakit seperti jantung, paruparu, lambung, sistem pencernaan, influenza, katarak, luka infeksi, dan masih banyak lagi khasiat dari madu. Gula dan mineral dalam madu berfungsi sebagai tonikum bagi jantung. Antioksidan madu diyakini mampu mencegah terjadinya kanker, penyakit jantung, dan penyakit lainnya. Selain itu madu juga dapat membunuh dan mencegah kuman untuk berkembang sehingga madu dipercaya dapat menyembuhkan berbagai macam luka seperti luka bakar, luka infeksi, luka setelah operasi dan lain-lain. Madu juga banyak sekali digunakan dalam dunia kosmetika, baik dalam bentuk sabun, masker, dan krim pelembut. Madu dapat menjaga kelembaban kulit dan memberinya nutrisi yang dibutuhkan. Komposisi kimia madu bervariasi tergantung 
pada sumber tanaman, musim dan metode produksi. Kondisi penyimpanan juga bisa mempengaruhi komposisi akhir, dengan peningkatan proporsi disakarida selama waktu penyimpanan berlangsung. Fruktosa (sekitar 38\% w/w) dan glukosa (sekitar 31\%) adalah dua gula utama yang terdapat pada madu secara umum, dengan jumlah sukrosa yang kurang (sekitar 1\%), serta disakarida dan oligosakarida yang lain. Potassium merupakan mineral utama pada madu. Selain itu mineral yang juga terkandung dalam madu adalah $\mathrm{Ca}, \mathrm{P}$, $\mathrm{Fe}, \mathrm{Mg}$, dan $\mathrm{Mn}$. Madu mengandung beberapa vitamin antara lain vitamin $\mathrm{E}$ dan vitamin $\mathrm{C}$ serta vitamin B1, B2 dan B6. Madu memiliki keasaman yang rendah

dengan $\mathrm{pH}$ sekitar 3,9. Kandungan air madu sekitar 17\%, dengan aktivitas air antara 0,56-0,62. Asam glukonat dan jumlah protein yang kecil serta asam amino juga terdapat pada madu.

Madu mengandung beberapa senyawa organik, yang telah terindentifikasi antara lain seperti polyphenol, flavonoid, dan glikosida. Selain itu, di dalam madu juga terdapat berbagai jenis enzim, antara lain enzim glukosa oksidase dan enzim invertase yang dapat membantu proses pengolahan sukrosa untuk diubah menjadi glukosa dan fruktosa yang keduanya mudah diserap dan dicerna. Begitu pula enzim amilase dan enzim lipase dan minyak volatil, seperti hidroksi metil furfural. Madu juga mengandung dekstrosa (gula yang ditemukan dalam tumbuhan), lilin, gen pembiakan, dan asam formik (Fitri, 2010: 51).

Telur ayam mempunyai struktur yang sangat khusus. Telur dihasilkan dari pembuahan sel telur pada hewan betina oleh sperma yang dihasilkan dari hewan jantan. Karena embrio yang terbentuk bertujuan untuk membentuk keturunan baru, isi telur terdapat bahan- bahan atau at-zat yang sama dengan hewan terbentuknya. Bentuk telur unggas bermacam-macam, umumnya telur memiliki bentuk yang bulat sampai lonjong. Perbedaan bentuk telur disebabkan dari beberapa factor antara lain : 1. Jenis hewan 2 . Umur hewan 3. Sifat-sifat fisiologis hewan Semua jenis telur memiliki struktur yang sama. Secara garis besarnya cangkang telur (kerabang), membrane telur, putih telur, kalaza dan kuning telur (Ponimin, 2006: 13).

Pada telur ayam sebagian besarterdiri dari bahan organik, pada putih telur komponen terbanyak adalah air disusul dengan protein, dan pada kuning telur bagian terbanyak juga air, lemak dan protein. Telur sebetulnya telah memiliki zat anti bakteri secara alami. Lisozim, yakni suatu zat bakterisida, yang terkandung dalam putih telur dan mampu menghancurkan bakteri. Selain itu, putih telur juga mengandung zat yang berdaya mengikat-besi (media pertumbuhan beberapa spesies pseudomonas). Telur mentah mengandung pula avidin yang dapat mengikat biotin. Biotin berperan sebagai factor pertumbuhan beberapa jasad renik (Arisman, 2009: 8).

Telur mengandung berbagai macam zat gizi yang penting bagi tubuh. Gizi telur sebenarnya berpusat pada kuning telur yang tinggi akan kadar protein, lemak, kalsium, fosfor, zat besi dan vitamin (Khamsan, 2004: 114). "Telur merupakan sumber protein bermutu tinggi, kaya vitamin dan mineral. Protein telur termasuk jenis protein sempurna karena mengandung semua jenis asam amino esensial dalam jumlah cukup dan seimbang. Asam amino esensial ini amat penting bagi manusia karena mutlak diperlukan tubuh tapi tidak dapat dibentuk sendiri oleh tubuh. Oleh karena itu, harus dipenuhi dari makanan. Telur mengandung protein lebih dari $10 \%$, bahkan sebutir telur ayam mengandung protein $12,8 \%$. Di dalam telur juga terdapat aneka vitamin $\mathrm{A}, \mathrm{B}, \mathrm{D}, \mathrm{E}$ dan $\mathrm{K}$. Telur tergolong makanan yang paling 
mudah dicerna. Nilai biologis protein telur 96\%. Artinya sejumlah itulah protein yang dapat diserap dan dimanfaatkan tubuh" (Haryoto, 1996: 9).

\section{F. KESIMPULAN DAN SARAN}

\section{KESIMPULAN}

1. Ibu hamil untuk mengubah persepsi keliru tentang mitos gizi pada masa kehamilan sebagai upaya pencegahan

2. Kejadian stunting melalui konseling berdasarkan umur ada pada kategori umur 20-35 tahun.

3. Ibu hamil untuk mengubah persepsi keliru tentang mitos gizi pada masa kehamilan sebagai upaya pencegahan kejadian stunting melalui konseling berdasarkan pekerjaan ada pada kategori IRT.

4. Ibu hamil untuk mengubah persepsi keliru tentang mitos gizi pada masa kehamilan sebagai upaya pencegahan kejadian stunting melalui konseling berdasarkan pendidikan ada pada kategori Pendidikan Dasar (SD).

5. Ibu hamil untuk mengubah persepsi keliru tentang mitos gizi pada masa kehamilan sebagai upaya pencegahan kejadian stunting melalui konseling berdasarkan paritas ada pada kategori multigravida.

6. Ibu hamil untuk mengubah persepsi keliru tentang mitos gizi pada masa kehamilan sebagai upaya pencegahan kejadian stunting melalui konseling berdasarkan usia kehamian ada pada kategori Kehamilan Trimester II.

7. Ibu hamil untuk mengubah persepsi keliru tentang mitos gizi pada masa kehamilan sebagai upaya pencegahan kejadian stunting melalui konseling berdasarkan Yang Melakukan Budaya/Tradisi Syukuran Empat Bulanan dan Tujuh Bulanan ada pada katagori yang melakuan acara.

8. Ibu hamil untuk mengubah persepsi keliru tentang mitos gizi pada masa kehamilan sebagai upaya pencegahan kejadian stunting melalui konseling berdasarkan Yang memiliki pantangan ada pada katagori memiliki pantangan dari makanan dan minuman.

\section{SARAN}

Bagi ibu hamill hendaknya lebih memperhatikan kesehatan selama kehamilan, dengan cara sering memeriksakan kehamilan kepada petugas kesehatan/bidan. Selain itu juga ibu hamil harus sering mengkonsumsi makan makanan yang bergizi yang banyak mengandung zat besi dan protein, dan tidak ada pantangan makan dan minuman pada ibu hamil.

\section{G. DAFTAR PUSTAKA}

Anderson, B.F. 1980. The Complete Thinker: A Handbook of Theniques For Creative and Critical Problem Solving. New Jersey: Englewood Cliffs.

Arikunto, S., 2009. Prosedur Penelitian Suatu Pendekatan Praktik. Edisi Revisi 6. Jakarta : Rineka Cipta.

Ai Yeyeh, R. 2009. Asuhan Kebidanan I (Kehamilan). Jakarta: Trans Info Media.

Ambarwati, S. 2008. Asuhan Kebidanan pada Masa Kehamilan. Salemba Medika. 
Ambarwati, W. N. 2006. Pendidikan

Kesehatan Mengatasi Keluhan Hamil pada Ibu-Ibu Hamil di Asrama Group II Kopasus Kartasura. Penelitian Reguler Universitas Muhammadiyah Surakarta. Tidak dipublikasikan

Arief, Nurhaeni. 2008. Panduan Lengkap Kehamilan Dan Kelahiran Sehat. Jogjakarta : AR Group

Achmad, Sri Wintala. 2014. Pamali dan Mitos Jawa. Yogyakarta: Araska

Badrujaman, 2008. Sosiologi Untuk Mahasiswa Keperawatan.Trans Info Media. Jakarta

Bayuandhy, Gesta. (2015). Tradisitradisi Adiluhung Para Leluhur Jawa : Melestarikan Berbagai Tradisi Penuh Makna. Yogyakarta

: Dipta.

Boy Suzanto, Ari Solihin. 2012. Pengaruh budaya organisasi, komunikasi interpersonal dan komitmen organisasi terhadap kinerja pegawai pada Unit Network Management System Infratel PT. Telekomunikasi Indonesia Tbk. Jurnal ekonomi, bisnis \& entrepreneurship, vol. 6, No. 2, oktober, 64-76.

Cicourel, Aaron V. (2013). Origin and Demise of Social-cultural Presentation of Delf from Birth to Death: Caregiver „Scafolding Practices Necessary for Guilding and Sustaining Communal Social Structure Throughout the Life Cycle. British Social Association.
2013.47:51.

Depkes RI. 2006. Profil Kesehatan Indonesia 2006. Jakarta

Dumatubun, A E, 2002, Kebudayaan Kesehatan Orang Papua Dalam Perspektif Antropologi Kesehatan, Jurnal Antropologi Papua Vol 1 No.1.

Dumatubun, AE. (2002). Kebudayaan, Kesehatan Orang Papua Dalam Perspektif Antropologi Kesehatan. Jurnal Antropologi Papua Agustus

2002. Jurusan Antropologi Fakultas Ilmu Sosial dan Ilmu Politik Universitas Cendrawasih.

Depkes RI. 2007. Keputusan Mentri Kesehatan RI

No:900/MENKE

S/VII/2007. Konsep Asuhan Kebidanan. Jakarta.

Depok: Pusat Penelitian Kesehatan Lembaga Penelitian Universitas Indonesia

Devy S. Hakimi, Prabandari, dan Mardikanto 2011. Perawatan Kehamilan dalam Perspektif Budaya Madura di Desa Tambak dan Desa Rapalaok Kecamatan Omben Kabupaten Sampang : Jurnal Promosi Kesehatan Vol 1, No.1, : 50-62.

Damayanti R.S., 2003. Childhood obesity : evaluation and management. Dalam Soebagijo A., Sri M., Askandar T., Hendromartono., Ari S., Agung 